DOI 10.22460/infinity.v5i2.213

\title{
AN ANALYSIS OF SELF-REGULATED LEARNING ON MATHEMATICS EDUCATION STUDENT FKIP UNDANA
}

\author{
Damianus D. Samo \\ Department of Mathematics Education Nusa Cendana University, Jalan Adisucipto Penfui Kupang, \\ Indonesia \\ demm_samo@yahoo.com
}

Received: June 15, 2016; Accepted: August 12, 2016

\begin{abstract}
This research aims to explore the differences among self regulating learning aspect of math education students-FKIP Undana involving three groups of students which are the first level (the first semester), second level (fifth semester) and third level (ninth semesters) students to review the ability of the individual. The samples included 167 students that consist of 60 students of the first level (18 with high ability; 27 with average ability and 15 with low ability), 64 students of the second level (16 with high ability, 30 with average ability and 18 with low ability) and 43 students of the third level (6 with high ability, 24 with average ability and 13 with low ability). This research is a survey research. The data collection is done by distributing questionnaires on self-regulated learning to those three groups. SRL questionnaire consists of 10 aspects, goal setting, motivation, learning difficulties analysis, selfefficacy, election strategies, meta cognition, resource management, performance evaluation, evaluation of the understanding, and self-satisfaction. Two-way ANOVA was utilized in the data analysis of this study. The results of the analysis showed that, the first level group is more excellent in SRL than two other levels. In a review of capabilities, the average comparison of all three groups showed that the average-ability students excel both the high and low-ability students in SRL.
\end{abstract}

Keywords: self-regulated learning

\begin{abstract}
Abstrak
Penelitian ini bertujuan mengekplorasi perbedaan setiap aspek self regulated learning mahasiswa pendidikan matematika FKIP Undana yang melibatkan tiga kelompok mahasiswa yakni kelompok mahasiswa tingkat 1 (semester I), tingkat 2 (semester V) dan tingkat 3 (semester IX) dengan tinjauan kemampuan individu. Sampel penelitian berjumlah 167 mahasiswa yang terdiri atas kelompok mahasiswa tingkat satu yakni 60 orang (18 kemampuan tinggi, 27 kemampuan sedang dan 15 kemampuan rendah). Kelompok mahasiswa tingkat dua sebanyak 64 (16 kemampuan tinggi, 30 kemampuan sedang dan 18 kemampuan rendah). Kelompok mahasiswa tingkat tiga sebanyak 43 (6 kemampuan tinggi, 24 kemampuan sedang dan 13 kemampuan rendah). Penelitian ini merupakan penelitian survey. Pengumpulan data dilakukan dengan menyebarkan angket sel-regulated learning pada ketiga kelompok tersebut. Angket SRL terdiri dari 10 aspek yakni penetapan tujuan, motivasi, analisis kesulitan belajar, self efficacy, pemilihan strategi, metakognisi, manajemen sumber daya, evaluasi performa, evaluasi pemahaman, kepuasan diri. Analisis data menggunakan ANOVA dua arah. Hasil analisis menunjukan bahwa mahasiswa tingkat pertama unggul dalam SRL dibandingkan dua tingkatan mahasiswa lainnya. Pada tinjauan kemampuan, perbandingan rata-rata untuk ketiga kelompok kemampuan menunjukan bahwa mahasiswa kemampuan sedang unggul dalam SRL dibandingkan mahasiswa berkemampuan tinggi dan rendah.
\end{abstract}

Kata Kunci: self-regulated learning

How to Cite: Samo, D.D. (2016). An Analysis of Self-Regulated Learning on Mathematics Education Student FKIP Undana. Infinity, 5 (2), 67-74. 


\section{INTRODUCTION}

Deductive reasoning is one of the characteristics of mathematics. This particular character which later makes mathematics is considered as a difficult subject for those who learn mathematics. In the context of learning mathematics, there are several main factors that influence mathematics achievement including academic achievement, self-efficacy, selfregulated, learning resources and learning styles (Murray, 2013). In this regard, Schraw \& Brooks (2015) reveal that the students can show a gradual but steady progress, if they follow four steps plan outlined below:

1. Spare sufficient time (for example, put more effort and never give up on learning when there is any obstacle appeared)

2. Compile an integrated basic knowledge

3. Develop a set of appropriate strategies for learning math, and

4. Believe that they can succeed if they are able to pass through the previous three steps.

Those four steps above can be illustrated as follows:

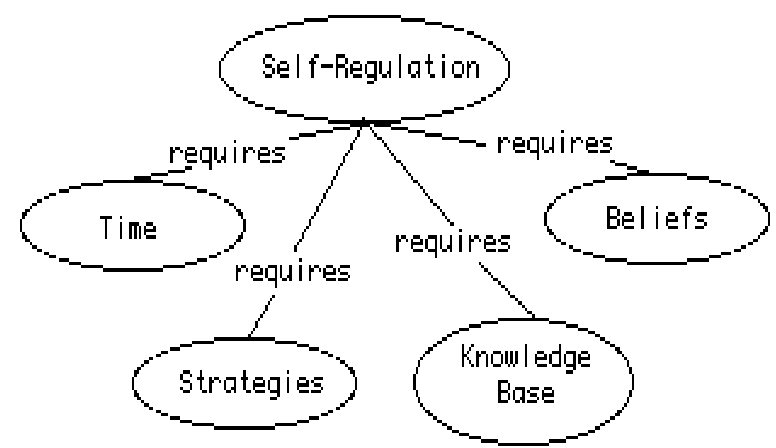

Figure 1. Four steps concept of self regulated

The four steps above describe the concept of self-regulation which is a concept that consists of four major components namely time, strategy, basic knowledge and belief. Using the foursteps plan above will help the students become independent since it gives them a clear plan to increase their success in learning mathematics and science, as well as help them to understand the integral relationship between knowledge, strategy and motivation. Without the selfregulatory skills, the students have greater risk of dropping out or failing because of their learning problems and lack of ability (Graham, 1991).

According to Zimmerman (1990), in general, the students can be described as having a (be) self-regulated that cover metacognition, motivation, and active behavior in their own learning process. The students personally initiate and direct their own efforts to acquire knowledge and skills rather than relying on teachers, parents, or other colleagues to achieve academic goals based on the perception of self-efficacy. This definition assumes the importance of three elements: student self-learning strategies, self-efficacy perception of performance skills, and commitment to academic purposes. Self-efficacy refers to the perception of a person's ability to organize and carry out the necessary actions to achieve desired performance of specific tasks skills (Bandura, 1986).

Murray (2013) explains that self-regulated learning can be defined as the ability of the students to monitor, evaluate and make best plans for their learning. These three capabilities will greatly support the students' progress because in each learning activity, the students not only learn to accept but also learn with plan and self control that is carried out continuously. 
Fadlelmula, Cakiroglu \& Sungur (2013) state that self-regulated learning is a complex and multidimensional construction that involves a number of cognitive, motivational, and behavioral aspects. Self-regulated learning theory shows that in order to have better understanding of how students become active agents of their own learning process, it is important to understand how the interaction between the motivational factors that may be associated with self-regulated and academic quality of the students. Self-regulated learning functions as a comprehensive framework for understanding how the students become active agents of their own learning process (Fadlelmula, Cakiroglu \& Sungur, 2013).

SRL development has a significance meaning in terms of increasing the students' math performance. Several studies have shown the fact that the students' good SRL will support their performance which eventualy lead them to the good learning achievement (Murray, 2013; Pape, Bell \& Yetkin, 2003; Malpas et al, 1999). Tang (2012) in his research on SRL mathematics class in pre university students shows that a high-ability subject on an easy mathematical topic has better SRL than the high-ability subject difficult mathematical topics. The high-ability subject is able to manage anxieties, organize themselves, and time better than the low-ability subject. This study seeks to explore and describe SRL students from the first to the third level with the existing three ability categories. The study involved three main parts namely planning (praaction), execution (action) and evaluation (postaction) divided into 10 aspects of measurement. The purpose of this study is exploring the difference of every aspect of self regulated in mathematics education students of FKIP Undana by involving three groups of students which are the first level (the first semester), second level (fifth semester) and third level (ninth semester) to review the individual ability. This study, in particular answers the following questions: is there any difference between self-regulated learning ability of students of high, average and low ability? and whether there is any difference of self-regulated learning of students at first level, second level and third level?

\section{METHOD}

This research is a survey research. The data collection was done by distributing questionnaires on self-regulated learning to those three groups. Valid questionnaire data obtained from the students of the first level which are 60 students with 18 represent high-ability students, 27 representing average-ability students and 15 represent low-ability students. The second group which is the second level consists of 64 students with 16 represent high-ability students, 30 represent average-ability students and 18 represent low-ability students. The third group which is the third level consists of 43 students with 6 represent high-ability students, 24 represent average-ability students and 13 represent low-ability students. Thus, the total of the sample were 167 students. The instrument used in this study was a questionnaire on selfregulated learning who have met the criteria of validity and reliability. The data were analyzed by using two-way ANOVA. The questionnaire contains 10 self-regulated learning aspects as follows:

1. Goals Setting
a. Set goals and targets to be achieved
b. Make a work plan
c. Prepare supporting learning aids before the lecture is held

2. Motivation
a. Interest in mathematics
b. Encouragement that make students enjoy to learn math
c. Belief in the importance of mathematics 
3. Analysis of learning difficulties

a. Recognize the internal difficulties

b. Strive to overcome the difficulties

4. Self Efficacy

a. Confidence in solving problems

b. Anxiety

5. Election strategy

a. Use your own strategy

b. Focus on problem solving

c. Discuss with friends and lecturers

6. Metacognition

a. Awareness of the problem solving process

b. Awareness of learning

7. Management of resources

Learning from a variety of sources

8. Evaluation of performance

a. Review on learning activities that have been done

b. Assess the learning progress

c. Observe the achievement of the learning objectives

9. Evaluation of understanding

Measure of understanding

10. The self-satisfaction

Satisfaction in the learning process

\section{RESULTS AND DISCUSSION}

\section{Results}

The valid questionnaire data were analyzed using two-way ANOVA with a review of semester levels and individual capabilities. Tests carried out on each SRL aspect with the students' average data in each category for selecting each item in that dimension. The results of descriptive statistical analysis using SPSS for the first SRL aspect of goal setting, which consist of nine statements of measurement for the first level student, second level student and third level student as follows :

Table 1. Descriptive Statistic

\begin{tabular}{cccccccccc}
\hline IQ & Level & Mean & SD & N & IQ & Level & Mean & SD & N \\
\hline \multirow{4}{*}{ High } & One & 3.1481 & .23632 & 15 & & One & 3.0370 & .37728 & 18 \\
& Two & 2.8272 & .36993 & 18 & & Two & 2.8611 & .11111 & 16 \\
& Three & 2.6667 & .19876 & 6 & Low & Three & 3.0513 & .24265 & 13 \\
& Total & 2.9259 & .34889 & 39 & & Total & 2.9811 & .28216 & 47 \\
\hline \multirow{4}{*}{ Average } & One & 3.1934 & .43098 & 27 & & One & 3.1352 & .37504 & 60 \\
& Two & 2.9074 & .43971 & 30 & & Two & 2.8733 & .36065 & 64 \\
& Three & 2.7361 & .20412 & 24 & Sum & Three & 2.8217 & .26130 & 43 \\
& Total & 2.9520 & .42051 & 81 & & Total & 2.9541 & .36816 & 167 \\
\hline
\end{tabular}

The data above is the measurement of SRL of goal setting aspect on the first, second, and third level students with the high-ability, average-ability and low-ability review. Data mean 
indicates, high-ability students at the first level have higher SRL of goal setting aspect is than the second and third level, it also happen to average-ability. Different things shown in the low-ability students where the first and the third level had SRL of goal setting aspect which are relatively similar and higher than the second level students. If we compare the mean among those three abilities, it shows the results are relatively the same, which means there is no difference between SRL of goal setting aspect among the three existing abilities. However, if we deal with the level (semester) point of view, it is shown that the first semester students (first level) has better SRL than the fifth (second level) and ninth semester (third level). That means there is no SRL difference among the firsts, second and third level students in learning goal setting and relevant activity aspects. Results of hypothesis testing population are presented as follows:

Table 2. Anova Analysis for the first SRL aspect of goal setting

\begin{tabular}{lccccc}
\hline \multicolumn{7}{c}{ Tests of Between-Subjects Effects } \\
\hline \multicolumn{1}{c}{ Source } & $\begin{array}{c}\text { Type III Sum } \\
\text { of Squares }\end{array}$ & df & Mean Square & F & Sig. \\
\hline Corrected Model & $4.488^{\text {a }}$ & 8 & .561 & 4.921 & .000 \\
Intercept & 1172.096 & 1 & 1172.096 & $1.028 \mathrm{E} 4$ & .000 \\
Ability & .196 & 2 & .098 & .859 & .425 \\
Level & 2.727 & 2 & 1.364 & 11.962 & .000 \\
Ability * Level & 1.258 & 4 & .315 & 2.759 & .030 \\
Error & 18.012 & 158 & .114 & & \\
Total & 1479.852 & 167 & & & \\
Corrected Total & 22.500 & 166 & & & \\
\hline
\end{tabular}

a. R Squared $=.199($ Adjusted R Squared $=.159)$

The first line shows the corrected model of the combined effects (together) between level and ability. Value of $F=4,921$ and $F_{\text {table }}(0.05)(8.158)=1.997437$. Because $F>F_{\text {table }}$ then Ho is rejected, which means there is a different SRL of goal setting aspect score among high, average and low-ability students with the first, second and third level students.

For the factor of ability, $F=0859$ and $F_{\text {tabel }}(0.05)(2.158)=3.053257$. Because $F<F_{\text {table }}$ then Ho is accepted, which means there is no difference in the value of SRL of goal setting aspect between students who have high, average and low-ability.

For the level factors, $F=11.962$ dan $F_{\text {tabel }(0.05)}(2,158)=3.053257$. Because $F>F_{\text {table }}$ then Ho is rejected, which means that there is at least one level which is different from the others.

In other words, each semester level has a significant role to the value of SRL of goal setting aspect. Based on the average value of SRL of goal setting aspect among low-ability students at the first, second and third level, it can be said that low-ability students at the first levels are able to set learning targets, create a lesson plan and prepare advice supporting learn better than low-ability students in the same level. For the ability and level interaction factor $\mathrm{F}=$ 2.759 and $F_{\text {table }(0.05)}(4,158)=2.428885$. Because $F>F_{\text {table }}$ then Ho is rejected, which means there are differences in self-regulated learning caused by the interaction between different students' abilities and level. Hypothesis testing for the tenth aspects of the SRL can be presented in the following table: 
Table 3. Summary Analysis of hypothesis testing of ten SRL aspects

\begin{tabular}{|c|c|c|c|c|c|c|c|c|c|c|c|}
\hline \multirow{3}{*}{$\begin{array}{l}\text { Aspect } \\
\text { of } \\
\text { SRL }\end{array}$} & \multicolumn{3}{|c|}{ First level student } & \multicolumn{3}{|c|}{ Second level student } & \multicolumn{3}{|c|}{ Third level student } & \multirow{3}{*}{$\begin{array}{c}\text { HA, } \\
\text { MA \& } \\
\text { KR } \\
(\alpha=0,05)\end{array}$} & \multirow{3}{*}{$\begin{array}{c}\text { FL, SL } \\
\& \mathrm{TL} \\
(\alpha=0,05)\end{array}$} \\
\hline & HA & AA & LA & HA & AA & LA & $\mathrm{HA}$ & $\mathrm{AA}$ & LA & & \\
\hline & Mean & Mean & Mean & Mean & Mean & Mean & Mean & Mean & Mean & & \\
\hline GS & 3.148 & 3.193 & 3.037 & 2.827 & 2.907 & 2.861 & 2.667 & 2.736 & 3.051 & $0.859 *$ & 11.962 \\
\hline MT & 2.961 & 3.025 & 2.944 & 2.778 & 2.953 & 2.912 & 2.639 & 2.698 & 2.891 & 3.407 & 12.348 \\
\hline LDA & 2.947 & 2.756 & 2.733 & 2.467 & 2.827 & 2.463 & 2.667 & 2.6 & 2.785 & $0.81 *$ & 8.956 \\
\hline SE & 2.389 & 2.272 & 2.222 & 2.5 & 2.333 & 2.208 & 2.111 & 2.083 & 2.551 & $1.428 *$ & $0.766^{*}$ \\
\hline ES & 2.948 & 3.029 & 2.444 & 2.852 & 3.026 & 2.778 & 2.704 & 2.889 & 2.897 & 18.289 & $1.484^{*}$ \\
\hline $\mathrm{MC}$ & 3 & 2.852 & 2.833 & 2.667 & 3.083 & 2.531 & 2.917 & 3.063 & 3 & 4.012 & 3.49 \\
\hline MR & 2.667 & 2.787 & 2.667 & 2.417 & 2.617 & 2.531 & 2.25 & 2.344 & 2.327 & 3.523 & 24.78 \\
\hline EPF & 2.833 & 2.885 & 2.633 & 2.611 & 2.753 & 2.506 & 2.633 & 2.738 & 2.6 & 14.734 & 8.798 \\
\hline EU & 2.778 & 2.42 & 2.333 & 2.556 & 3.056 & 2.646 & 2.111 & 2.417 & 2.539 & 3.424 & 17.131 \\
\hline SSF & 3 & 2.796 & 3 & 3 & 2.5 & 2.656 & 2.667 & 2.625 & 3.039 & 10.48 & 5.648 \\
\hline
\end{tabular}

1) $\mathrm{HA}=$ High Ability, $\mathrm{AA}=$ Average Ability, LA = Low Ability

2) $\mathrm{GS}=$ Goal Setting, MT = Motivation, LDA = Learning difficulties ability, SE = self efficacy, $\mathrm{ES}=$ election strategy, $\mathrm{MC}=$ metacognition, $\mathrm{MR}=$ Management resources, EPF $=$ evaluation of performace, EU = evaluation of understanding, $\mathrm{SSF}=$ Self Satisfaction

Furthermore, for the ability factor of the second aspect of SRL, F $=3.407$ and $F_{\text {table }}(0.05)$ $(2.158)=3.053257$. Because $\mathrm{F}>\mathrm{F}$ table then Ho is rejected, which means that there is at least one level of ability which is different from the others. Based on the average, Low-ability students have better SRL motivation than the average and high-ability students. In other words, the level of ability has a significant role to the value SRL motivational aspects. For the semester level, $\mathrm{F}=12.348$ and $\mathrm{F}_{\text {table }}(0.05)(2.158)=3.053257$. Because $\mathrm{F}>\mathrm{F}$ table then Ho is rejected, which means that there is at least one level which is different from the others. In other words, level of the semester has a significant role to the value SRL aspect motivation.

\section{Discussion}

Summary of hypothesis testing of ten SRL aspects, with the ability review, showed that whether high, average and low-ability students have different motivation, strategies election, metacognition, resource management, performance evaluation, understanding evaluation, and self-satisfaction aspects of SRL. In the average comparison for those three ability groups, low-ability students excel at motivation aspect of SRL, high-ability students excel at selfsatisfaction aspect of SRL, while average-ability students lead in the election strategy, metacognition, resource management, performance evaluation, evaluation of the understanding aspects. Seven quantitatively different aspects with five dominant aspects of the average-ability students show possible interpretation that the average ability students were able to arrange themselves and the resources as well as evaluate them in learning better. This condition is possible because the average ability students were aware that it needs more effort to reach a high ability and at the same time do not fall into the low-ability level. Qualitative interpretation overview of this condition can be explained by qualitative research later. This finding is in contrast to some previous findings (Tang, 2012; Tang 2013; Yip, 2009; Yip and Chung, 2005) which reveal that the high-ability students have better SRL than low one. This finding opposes against the facts of a common research which states that SRL has a good 
contribution in improving math skills (Murray, 2013; Pape, Bell \& Yetkin, 2003; Malpas et al, 1999).

At the review of semester level, there are also seven significantly different aspects of SRL namely motivation, analysis of learning difficulties, metacognition, resource management, performance evaluation, evaluation of the understanding and self-satisfaction. In average comparison of those three semester levels, the first level (first semester) excels in the motivation, the analysis of learning difficulties, metacognition, resource management, performance evaluation and self-satisfaction aspect of SRL. The second level (fifth semester) leads in evaluating of understanding aspect while the third level (ninth semester) does not excel in any aspect of SRL. Students of the first level which are in the first year at the University seem to have better motivation, setting, and self-evaluation in learning. This may be due to a great motivation to enter the University that makes the students organize themselves well in learning. It eventually appear that they are different from the second and third level students.

It is interesting that in every SRL aspect analysis which done by using ANOVA, goal setting and self efficacy have no difference in both ability and level reviews. The possible interpretation is that the goal setting aspect is done by almost all of the students in different level and ability. While self-efficacy which is more specific to the domain aspects of perceived anxiety becomes an aspect that felt by all of the students in different level and ability.

\section{CONCLUSION}

The main objective of this research is to analyze the SRL difference among the first, second and third level students with the students' individual capabilities review. The results of the analysis showed that the average ratio of the three semester level. First level students excel at SRL than the students of two other levels. In the capabilities review, the average comparison of all three groups showed that the average-ability students were superior in SRL.

Some studies show that SRL has a good mathematical performance impact. Increasing SRL contributes in improving math ability. This particular study reflects that there is an equal ratio between individual abilities and SRL (Murray, 2013; Pape, Bell \& Yetkin, 2003; Malpas et al, 1999). The low-ability students, should be supported by SRL development which in this study include strategies, metacognition, resource management, performance evaluation, evaluation of the understanding and self-satisfaction that still quite low. This development has to be conducted so that the low-ability students will be able to have better learning achievement. In line with the low-ability students, high-ability students should be supported to improve their SRL to be able to improve their learning performance. Students at the second and the third level should always be supported to develop their decreasing SRL

\section{ACKNOWLEDGMENTS}

Thanks to students of mathematics education FKIP Undana Kupang who have taken the time been the subject of research and honestly fill this instrument. 


\section{REFERENCES}

Bandura, A. (1986). Social foundations of thought and action: A social cognitive theory. Englewood Cliffs, NJ: Prentice-Hall.

Fadlelmula, K. F., Cakiroglu, E., \& Sungur, S. (2013). Developing a structural model on the relationship Among motivational beliefs, self-regulated learning strategies, and achievement in mathematics. International journal of science and mathematics education 2013, national science council, Taiwan 2013.

Graham, S. (1991). A review of attribution theory in achievement contexts. Educational Psychology Review, 3 (1), pp. 5-39.

Murray, J. (2013). The factors that influence mathematics achievement at the Berbice campus. International journal of business and social science. 4 (10). pp.150-164.

Pape, S.J., Bell, C.V., \& Yetkin, I. E. (2003). Developing mathematical thinking and Selfregulated learning: a teaching experiment in a Seventh-grade mathematics classroom. Educational studies in mathematics, kluwer academic publishers, pp.179-202.

Schraw, G., \& Brooks, D.W. (2005). Helping students self-regulate in math and sciences courses: improving the will and the skill. University of Nebraska-Lincoln, Lincoln, NE.

Tang, E. L. (2012). Self-regulated learning between low-, average-, and high-math achievers among pre-university international students in Malaysia. European Journal of Social Sciences, 30(2), pp.302-312.

Tang, E. L. (2013). Self regulated learning of pre university students in mathematics classroom. Journal of Education Science \& Phychology. 3 (2), pp. 40-47.

Yip, M. C. W. (2009). Differences between high and low academic achieving university students in learning and study strategies: A further investigation. Educational Research and Evaluation, 15(6), pp. 561-570.

Yip, M. C. W., \& Chung, O. L. L. (2005). Relationship of study strategies and academic performance in different learning phases of higher education in Hong Kong. Educational Research and Evaluation, 11(1), pp. 61-70.

Zimmerman, B. J. (1990). Self-regulated learning and academic. Journal of Educational Psychology, 25 (1), pp. 3-17. 